LA W RENCE LIVERM ORE N A T IO N A L LABORATORY
The Enemy is Still Below: The Global Diffusion of Submarines and Related Technology

K. G. Weiss

July 12,2012 
This document was prepared as an account of work sponsored by an agency of the United States government. Neither the United States government nor Lawrence Livermore National Security, LLC, nor any of their employees makes any warranty, expressed or implied, or assumes any legal liability or responsibility for the accuracy, completeness, or usefulness of any information, apparatus, product, or process disclosed, or represents that its use would not infringe privately owned rights. Reference herein to any specific commercial product, process, or service by trade name, trademark, manufacturer, or otherwise does not necessarily constitute or imply its endorsement, recommendation, or favoring by the United States government or Lawrence Livermore National Security, LLC. The views and opinions of authors expressed herein do not necessarily state or reflect those of the United States government or Lawrence Livermore National Security, LLC, and shall not be used for advertising or product endorsement purposes.

This work performed under the auspices of the U.S. Department of Energy by Lawrence Livermore National Laboratory under Contract DE-AC52-07NA27344. 
"The Enemy is Still Below: The Global Diffusion of Submarines and Related Technology"

A Workshop Sponsored by

The Center For Global Security Research

Lawrence Livermore National Laboratory

In Cooperation With

The U. S. Naval Postgraduate School

30-31 May, 2002, Monterey, California ${ }^{1}$

Summary of Discussion

By Kenneth G. Weiss, Ph.D.

\section{Introduction}

The spread of submarines and related technology is an end product of globalization. Globalization is not a new story. By one estimate, our ancestors first crossed out of Africa roughly 80,000 years ago, and began the process that we now call globalization. With the dispersion of people around the world came the development of culture and civilization as well as the spread of ideas, goods, and technology. The process of globalization then is a long-standing one, not an innovation of the late $20^{\text {th }}$ and early $21^{\text {st }}$ centuries. Over the millennia, this process has been an uneven one. Globalization has often caused great disruptions even to the societies that initiated various innovations in culture and civilization, including science and technology. Indeed, many cultures and civilizations have disappeared while some regions failed to advance as rapidly as others, so the process of globalization is not just one of continuing progress.

Globalization in the current era seems to be penetrating the most remote corners of the world at a remarkable rate as a result of advances in science and technology, particularly information technology. The diffusion of science and technology is not necessarily a benign development. It could increase the

\footnotetext{
${ }^{1}$ *The Center for Global Security Research (CGSR) at Lawrence Livermore National Laboratory (LLNL) has been sponsoring a series of workshops, leading eventually to a conference, focusing on the future of science and technology over the next fifty years, and its potential impact on national security. As part of this project, CGSR sponsored a workshop in cooperation with the U.S. Naval Postgraduate School (NPS) in Monterey, California on May 30-31, 2002 on the diffusion of submarines and related technology as a case study. This workshop was hosted by Dr. Ronald F. Lehman II, Director of the Center for Global Security Research, and RADM David R. Ellison, Superintendent of the U.S. Naval Postgraduate School, and organized by Dr. Kenneth G. Weiss, former CGSR Fellow/LLNL, with Professor Clyde Scandrett of the U.S. Naval Postgraduate School, and with the invaluable support of Tami
} Alberto of CGSR/LLNL with Stephanie Brand of NPS. The format of the workshop was interactive emphasizing discussion among the invited specialists from the Navy, OSD, various national laboratories, academia, and think tanks, along with some briefings to inspire discussion. Research and conclusions based on data available at that time.

Approved for public release; further dissemination unlimited 
potential for a global military industrial base that may have an adverse affect on world stability in the future. For example, the spread of key military capabilities, like submarines, could still have an impact, especially over the longer term, on the US capability to project power overseas.

Globalization can also spread tensions and conflict. Thus, the US ability to use its military forces, especially naval forces, to influence events globally in support of peaceful change may decline, particularly in the face of the stresses and strains in the current international system, largely dominated by the West including Japan. For example, demographic imbalances may increase considerably with violent consequences. According to the UN, the world's population will increase from 6 billion to 9 billion people by mid-century before leveling off. At the same time, population is slowly declining in the West. Yet the West's lifestyle and culture will continue to be a disruption in more traditional societies, less accustomed to rapid change. The combination could be explosive.

Submarines are ideal for a case study in globalization's technology diffusion. The development of submarine technology can trace its origins back to Alexander the Great, and a number of countries contributed to submarine development. For example, in $1850 \mathrm{~W}$. Bauer built his first submarine at Kiel by Howaldt (the Braundtaucher). The Braundtaucher was powered by two men turning large thread wheels attached to a crude propeller by a simple gear mechanism. The ballast tank was below deck, and operated by hand pumps. Bauer's Russian submarine boat was built at Leuchtemberg Works, St. Petersburg in May 1855 and was received by the Russian Admiralty on November $2^{\text {nd }}$ of the same year. He called it "Le Diable Marin." Other countries including France and Spain developed submarine designs. In 1885, Anglican Reverend George W. Garrett tested the steam-powered "Resurgam." By the 1890 s, according to Submarines of the World: "the basic problem of submerging and returning to the surface had been solved, but the question of propulsion was not solved until J.P. Holland established that the solution was the use of electric storage cells with internal combustion engines being employed on the surface for both propulsion and the recharging of batteries. Practical use of the various options - petrol, kerosene, and diesel - eventually established the latter as the most satisfactory and least dangerous, and for fifty years diesel-electric was the only practicable means of propulsion with steam an unpopular and dangerous alternative," Thus, John Holland, a former Christian Brother of Ireland who became an American, helped transform the submarine into the practical weapon of war as we know it today. Indeed, according to The Submarine Book by Chuck Lawliss, John Holland was "the man who almost single handedly created the modern submarine. ." (2) His "second submarine, the Holland VI, launched the following year (1898) was the forerunner of all modern submarines."3

In 1900, the US Navy bought its first successful submarine, as we know it, from Holland who then founded the company that is today known as General Dynamics Electric Boat. These submarines quickly spread to Japan, the United Kingdom, and Russia. Another American, Simon Lake developed a competing design, and sold boats to Russia and Austria. He ". . then set up a joint operation with Krupp armament makers in Germany. He neglected to protect his patents in Germany, however, and received no royalties." 4 According to Lawliss, "by 1914 Germany had 29 submarines, and both Britain and

\footnotetext{
${ }^{2}$ David Miller, Submarines of the World, Salamander Books, Ltd., London, United Kingdom, 2002, p.8. ${ }^{3}$ Ibid., p.59
}

${ }^{4}$ Ibid., p.64 
France had about twice that many. The major powers built their own submarines, Britain and France from modified John Holland designs and Germany from Simon Lake's design. German submarines had the advantage of a German invention, the diesel engine. Remarkably reliable, it produced no spark, and diesel oil was not as dangerous to have aboard a submarine as gasoline. Diesel engines gave U-Boats, from the German unterseeboat, a range of 3000 miles, which would work to Germany's advantage. By contrast, Britain and France developed shorter-range submarines:"

"small, sturdy, and fast." 5

Submarines played key roles in both World Wars, and the nuclear submarine, also first developed by the US, spread to the other major nuclear powers during the Cold War. In the post Cold War era, submarines are likely to play even more important roles as the vulnerability of surface ships and associated aircraft increases. (Certainly, the Chinese think so, and China is potentially a major player in a future multipolar world. As one Chinese PLA officer stated, the battleship dominated the seas in World War I, and the aircraft carrier in World War II, while the submarine will dominate in future wars).

The US response to 9/11/01 in Afghanistan against the Al Qaeda terrorist organization and its Taliban supporters highlighted the US's continuing need to project and sustain power in distant theaters as well as deny sanctuary to its enemies. US naval capabilities are a key factor in the nation's ability to project power in remote regions of the world. In this regard, the US Navy's strategy shifted at the end of the Cold War from open ocean blue water operations to the support of joint operations in littoral waters. This strategic shift increases the potential threat from conventional foreign submarines (SS) and mines, while nuclear submarines (SSN) will also remain a threat. The US may be lagging in doctrine, strategy, and tactics in dealing with these capabilities. There is already a problem in countering the current foreign submarine threat, and it could become worse in the future. Moreover, the events of 9/11/01 emphasized the need to "expect the unexpected," and focused US attention on homeland defense. Submarine forces could become instruments of terror in the future. Hostile submarine forces, whether conventional or nuclear, in time, could conceivably pose a threat, conventional or WMD, to the US homeland. As Secretary Rumsfeld has pointed out, the US should not plan to fight this or that country, but examine vulnerabilities and how an enemy might exploit them. Or as Lord Palmerston once put it, nations do not have permanent allies, only permanent interests. Thus, the US must take into account a potential enemy's ability to exploit any submarine-related vulnerability.

This summary of the workshop's discussion focuses on three key questions: What do we know or agree on; what we disagree on or don't know; and what requires additional research? In this regard, the following reflects the efforts of the author to summarize and does not completely mirror the complexity and richness of the views expressed at the meeting. (The author wishes to thank those who commented on an earlier draft, including those who were unable to attend the workshop. He tried to incorporate the comments as much as possible in this draft, including much of the language used by the commentators.)

\section{What Do We Know or Agree On?}

${ }^{5}$ Ibid., p.68 
- Despite a decline in the numbers of submarine forces in general following the Cold War, US ability to conduct anti-submarine warfare has declined even more. Allied ASW capabilities have declined as well. There is some disagreement on the number of submarines deployed around the world. (By conservative estimate there were 458 foreign submarines in 1997, and 364 in 2002; another estimate, by one specialist at the conference, claims that there were over 800 submarines in 1997 and 624 in 2002 including allied submarines.) Currently, the US has 52 SSNs, 18 SSBNs, 1 SSAN, and 1 SSA (see list of terms). The US Navy needs roughly 4 submarines to keep one forward deployed.

- Forty-one countries have submarines in their naval inventories, over 30 of these are in Russia, China, and the developing world - one specialist claims that 50 countries have submarines with over 35 in the developing world, including Russia and China. (Developing countries (or emerging nations) in this paper are not necessarily economically underdeveloped or technologically interior. In fact, Russian submarines and related systems were very technologically advanced when designed, although little has been done to update them since. Some nations in this category like Singapore are as economically advanced as some Western countries.) There are currently approximately 175 conventional submarines in the developing world not including Russia and China. Russia and China also have roughly 45 nuclear (SSN/SSBN), eight conventional and 6 nuclear (SSN/SSBN), 58 conventional, respectively.

- With the Cold War over, the USN has cut back on ASW platforms, surface, air and subsurface, and related technology. Furthermore, the US has reduced practicing ASW operations below levels declared needed. Both Atlantic and Pacific commands are concerned about the decline in US ASW capabilities.

- The very presence of potentially hostile submarines severely complicates US naval operations and the ability to project power ashore.

- Conventional submarines can be used for coastal defense (Anti-Surface Warfare (ASUW), AntiSubmarine Warfare (ASW), merchant shipping interdiction, power projection, offensive and defensive mining, strategic missile platforms, intelligence gathering, special forces etc., although nuclear submarines provide greater range, speed, power, and endurance.

— Submarines/submersibles could be used for drug running, piracy or terrorism.

- Conventional diesel submarines are difficult to detect because they are quieter than the Soviet nuclear submarines that we hunted in the Cold War, an important advantage because those who can shoot first have the advantage. (One submariner said that he worried about conventional submarines and lamented the day when the US decided to stop building them. In numbers they can add real value to the defense of a nation; they can go where nuclear submarines cannot, and they can do things like sit on the bottom in places that nuclear boats cannot.)

- These submarines have/may become increasingly more sophisticated:

- Better batteries (snorkel every four days)

- Air Independent Propulsion (there are a number of different systems coming into service, but they will give conventional submarines the ability to stay submerged for 14-21 days at a time. See list of terms.) 
- SSn (Small nuclear plant to generate power to charge batteries used for propulsion - has yet to generate much interest)

- Sophisticated submersibles

- Integrated fire control systems for weapons, sensors, and targeting;

- Advanced weapons, such as the advent of largely unjammable wake following torpedoes, submarine launched missiles with anti-surface, subsurface, and anti-air capabilities and improved naval mines;

- Advanced passive and active sensors, such as improved microelectronics, hull/bow mounted arrays and flank and towed arrays;

- Quieting technology, such as hull mounted anechoic tiles, mounted machinery, permanent magnetic motors, improved propellers, etc.;

- Improved countermeasures for survival;

- Automated systems requiring fewer (and perhaps less experienced) personnel and less for operations, modular construction, etc.

- Even older conventional submarine forces pose a threat. For example, the Chinese deployed a large number of Romeo submarines in a recent exercise, and such deployments are difficult to detect and track.

- The advent of submarines equipped with Air Independent Power (AIP), which can be as quiet as diesel submarines running on batteries while submerged, may make it even more difficult to detect conventional submarines because they will be able to remain submerged for weeks at a time, instead of days like diesel submarines. (Conventional submarines on batteries can generally run more quietly than nuclear submarines.)

- Even though some countries are opting largely to develop, acquire, or upgrade conventional submarine capabilities, nuclear submarines are not going away. Although the Russians are retiring or dismantling their older nuclear submarines, they are trying to retain as much of their construction capabilities as possible, and they are continuing to work, however slowly, on newer classes of SSNs and SSBNs, designed prior to 1991. The Russians are also assisting the Chinese in developing new classes of SSNs and SSBNs, and Moscow is assisting as well the Indian nuclear submarine program. The UK has leased its conventional submarines of the Upholder class to Canada to concentrate on nuclear submarines. France has dispensed with its conventional submarines in favor of its nuclear submarine program. However, the French are continuing conventional submarine exports to keep open their shipyards.

- Nor can we discount improvements in stealth and other capabilities of foreign nuclear submarine forces in the future, specifically the Russians and the Chinese. The Soviets made significant advances in quieting their nuclear submarines by the end of the Cold War, and the Russians will probably again make advances in the future. The Russians are generally willing to sell this technology. With their help, 
the new Chinese attack submarine under development may have the capabilities of a Victor III, which would represent a significant advance over the Chinese Han and Xia.

- India has become a regional naval power with a significant submarine force. According to one expert, the Indian Navy is currently the third largest naval power in the Asia-Pacific region after China and Japan. India is rapidly expanding the country's strategic arms to operate beyond the Indian Ocean region and in this connection the acceptance of the "30 Year Submarine Program Perspective" by the Indian government should be noted. The Indian Navy plans to acquire 24 submarines including 5 SSNs for operations covering not only its territorial waters, but also for sea denial operations against both Pakistan and China. Thus, the Indian submarine force will have the capability to operate as far as the South China Sea.

- Modern submarines and related technology will spread over time. Much of the technology can simply be purchased outright or manufactured on co-production and licensing arrangements from Russia, Germany, or France. These three countries also have a significant market for associated systems. (Germany though does not export some crucial technologies that would allow a country to design a submarine in its own, according to one expert). For example, Russia, Germany, and France account for $67 \%$ of the sales for heavy torpedoes. Indeed, the Russian Shkval torpedo or underwater missile available for export has a speed of 200 knots and has no Western counterpart. (Although one specialist claims that it has limited usefulness, and is not in service in any other country - yet.) The Germans guarantee logistic support for their submarines as long as the buyer does not go to war against them. Russia, Germany, and France are also helping other countries through sales and technology transfer to improve the production capabilities of countries like China, India, Pakistan, South Korea, Turkey, Greece, Brazil, etc.

- Moreover, there are other factors affecting the diffusion of submarines and related technology. For example, as the US and other countries rely more and more on commercial-off-the-shelf technology (COTS) for its weapons systems, other countries will have similar access to COTS for their systems development. (Defense software is often tailored by industry, but much of it is increasingly COTS as the basis.) Advances in submarine and related technology can also be obtained on an unclassified basis in the US (and probably elsewhere) through conferences, publications, patents, Defense Technology Information Center (DTIC), National Technical Information System (NTIS), military and technology related websites on the internet, company websites, etc. (However, one specialist points out that extracting useful technical information from the net and elsewhere may be harder than we think.) For example, the Swedes have been using modular construction for their submarines since the 1960s based on a US technology invented then. European defense/submarine manufacturers seem to be freer with providing technical related information than the US in order to make sales. They are also generally willing to transfer technology through licensing or co-production arrangements. (Even so, one expert believes that increasingly in military development the problem is software, not hardware - and software is generally not a COTS product.) What cannot be bought or obtained through research can be stolen potentially through espionage or other illicit arrangements, like the manufacturing capability to produce quiet propellers that the Soviets obtained from Japan's Toshiba Corporation.

- Another reason submarine technology will spread over time: developing countries, including Russia and China, may gain in scientific and technological expertise because they are training many of their students in the West, especially in the United States. In the 1970s, the State Department issued roughly 60,000 student visas; in 2001, the State Department issued 350,000 student visas. Practically all the 
scientists in the Iraqi WMD programs were trained in the West, especially the US, including the father of the Iraqi nuclear weapons program. Many of these students are from Asia.

- International export controls are inadequate, making it difficult to control the diffusion of submarine technology. The Wassenaar Arrangement replaced COCOM (and even includes Russia as a member) in controlling munitions and dual-use technology to rogue states and regions of instability. Wassenaar controls are extremely weak, and its members' national controls are unreliable. For example, Russia is apparently willing to export most weapons technology to China except nuclear weapons and ballistic missiles. The Russians are also assisting the Indian nuclear submarine project (ATV), and helping them to develop missiles for the ATV that the Indians could use for nuclear warheads. Moreover, the Russians are unwilling to forego needed income from weapon sales, and Moscow would not be amendable to a US effort to negotiate restraints on transfers of submarines or related technology. In addition, many Russians resent US naval superiority and sole superpower status. China has had a traditional aversion to informal supplier control regimes, seeing them as an effort to retard the development of emerging nations. (Others do not necessarily disagree concerning the difficulties of coming to agreement with other countries concerning supplier restraint, but point out that many believed that there was little chance of success in negotiating supplier regimes like the NSG, MTCR, and Australia Group, and thus efforts to strengthen Wassenaar or make other informal arrangements or requests concerning restraint in specific transfers may be worth exploring.)

- A coordinated ASW effort is necessary. (As great as a six to one ratio of surface, air, and subsurface platforms, may be required to deal with a single potentially hostile submarine, according to one specialist.) There are also promising research and development efforts underway to improve our ability to detect conventional submarines, but they remain in $R \& D$ because they have not been given enough priority to move towards the production phase.

- One specialist commented that during the Cold War, the US could fight Soviet submarines on a global basis, at the very least as soon as they left port, and mounted a kind of defense in depth. Geography was relatively fixed, and US submarines could exploit choke points and fixed long range sensors (SOSUS). The US submarines could also take advantage of deep ocean phenomena, such as convergence zones. Moreover ASW was often considered a statistical proposition: success was defined by killing Soviet submarines while holding losses to acceptable levels. As defined by various conflict scenarios, geography can be more restrictive today. The US almost exclusively operates high value assets, and the loss, or even the serious damage, of one such unit might be disastrous. Littoral waters may be shallow and littered with wrecks and other confusing features. Although an enemy force may be small, the numbers the US deploys to any particular place may be quite limited, nothing like Cold War numbers.

- A potential enemy might use its submarines to sink a US ship or even an SSN if they could, and we might not even know who did so. They could also lurk outside a US or overseas base, and attack a US SSN or SSBN as it is entering or exiting port. There are thousands of sailors aboard a single US aircraft carrier, and a submarine-related sinking of a carrier would be the equivalent to the destruction of the World Trade Center towers. US amphibious ships and re-supply vessels are particularly vulnerable, and their loss could cripple our ability to project power in a crisis or conflict. Furthermore, in the age of supertankers and giant container ships, the impact of a campaign against merchant shipping might be felt more quickly than in World War II.

Approved for public release; further dissemination unlimited 
- Conventional submarines could be used to deliver WMD, nuclear or CBW, against the US homeland or bases overseas. According to one expert: the use of submarines as strategic platforms by emerging nations would be a serious development possibly forcing us to change the entire focus of US naval investment and even curtail or abandon force projection abroad. No other maritime platform has as much potential for disrupting US national strategy. On the other hand, he did not think terrorist submarines were a serious threat because terrorists would need so many trained people working together. However, nationalist forces are a different proposition. Relatively inexperienced submariners might well fail to penetrate the screen of a battle group, but on a voyage to the US they would have a relatively free ride, particularly given the virtual abandonment of SOSUS.

- With a somewhat different degree of emphasis, a submariner states that submarines could be deadly weapons of terror in the hands of smart operators. A trained submariner could take one into any harbor in the world. This is a frightening prospect if combined with a weapon of mass destruction and a suicide crew, although how likely it would be that an intelligent submarine crew would also be suicidal is unclear. Homeland protection against a terrorist attack would be quite challenging. On the west coast, deep water exists right up to the harbor channels. Indeed, US submarines transit the Straits of Juan De Fuca submerged until well inland where the shipping traffic thickens. Terrorist submarines could remain stealthy until the last moments when they could penetrate on the surface with decks awash and no more radar profile than a small fishing boat or pleasure craft. It is not clear that San Diego and/or Pearl Harbor could respond quickly enough to avoid disaster even if a suicide submarine were observed as it entered the channel. On the east coast, the wide and shallow continental shelf complicates matters greatly, but a submarine attack could still be mounted by a determined and well-trained crew. Tactics against such attacks would have to rely heavily on HUMINT and SIGINT of impending threats so that intruders could be prosecuted far out to sea and so appropriate barrier patrols could be established near sensitive harbors.

- In regard to "expect the unexpected," an effort by terrorists, anti-nuclear activists, or a rogue state's special forces to seize or attack an SSN/SSBN at a US or overseas naval base, with incalculable consequences for US resolve and for the future of the nuclear navy, cannot be wholly discounted. They would not necessarily have to sail it, but destroy it, contaminating with radiation the surrounding waters. One submariner believes: that the US must better protect its submarines from terrorist hijackings. It would be difficult but conceivable for Special Forces to take over a nuclear submarine. Whether or not they would be able to operate it is another question, but takeover is conceivable. Even though efforts have been made to increase security, a nuclear submarine hijacking remains a troublesome concern.

- US efforts to improve ASW capabilities are not likely to increase in the near future. Some argued that it would not improve until the Navy revived a high level organization dedicated to ASW. Dramatically, others argued that the US would not concentrate on ASW until a US ship was sunk by a foreign submarine. This has not happened in 60 years and the survival issues of the Cold War and the Soviet SSBN threat are no longer pushing investment. However, one submariner argued that US ASW may not compare with 1990, but US submarine tactics are good, and were practiced often at least until 4 years ago. US submarines worked hard on countering the diesel submarine threat in littoral waters. It takes team-work and several platforms, but it can be done effectively if we have knowledge that a submarine threat is likely.

\section{What We Do Not Know or Disagree On?}


- Some argue that the foreign submarine threat is overstated. Not only have the numbers of submarines declined, but also some countries are hard pressed to operate the submarines they have. Modern submarine forces, even conventional ones, have become so expensive that many countries have either decided that they cannot afford them or limit the numbers that they buy or build. Yet there was agreement that our ASW capability has also declined. Moreover, others argue submarines that did not appear to be operational have surprised us in the past.

- There has been a consolidation in the number of countries and companies building submarines. In the West, the Germans have all but cornered the market for conventional submarines with the French remaining their only serious competitor (It is not clear if a US bank's purchase of HDW, the German submarine manufacturer, which also owns the Swedish submarine firm, Kockums, will give the US greater control over German sales in specific cases, but it probably will not because the Germans have generally resisted US efforts to control the sales of US owned companies in Germany). For example, the Germans and French have been willing to sell submarines in regions of tension, such as South Asia. Yet those countries that have had submarine production capabilities like the UK and Italy seem to be trying to retain some residual capability so that they can ramp up in the future should the international environment or the market change.

- Outside the West, the Russians are the only serious player, with the possibility of China and perhaps India becoming producers in the future. There was disagreement on how successful the Russians have been in making sales. The Russians have been working on AIP since the 1970s, and they envision equipping the Amur-class submarines, the follow-on class to the Kilo with a fuel cell based AIP system. However, the first submarines of the class will rely on diesel engines and batteries for propulsion. The Russians have had difficulty in developing an AIP system and believe that there is still a future for diesel-electric propulsion. They hope to sell the Amur to India and China, but may have a hard time doing so. The Chinese are also very interested in acquiring or developing an AIP submarine capability. They have been actively seeking teaming arrangements for AIP development. They have also been trying to improve their indigenous conventional submarine manufacturing capabilities, while acquiring nine more Kilo-class-submarines from Russia. There are reports that the Chinese may be developing an AIP system for their Ming-class submarines. They have been actively seeking teaming arrangements for AIP development. Nevertheless, some point out that the Chinese have been experiencing significant difficulties developing their new Song-class of conventional submarines. So their lack of success at developing submarine related technologies may encourage them to buy more from Russia.

- Although other developing countries, such as Brazil, Chile, South Korea, etc. have some capability to assemble submarines, they remain dependent on countries like Germany to complete them. However, others argue that these countries have ambitions to eventually develop independent capabilities of their own, and they could become sources for submarines and related technology to rogue states or regions of tension. For example, Germany and France have been willing to sell to India and Pakistan, and these countries could become sources for submarines and associated capabilities in the future.

- A few countries have decided to upgrade existing platforms or buy older submarines from other countries. However, even modernizing old platforms can be very expensive. For example, there was some disagreement on how likely it is that emerging nations' submarine forces will buy wake homing torpedoes from the Russians. 
- AIP is not cheap. AIP can add as much as $15-20 \%$ to the procurement cost of a submarine and three to eight times to the operating cost as compared to a diesel-electric submarine. Some argued that AIP might not prove to be as attractive as some think, and that diesel submarines may remain sufficient for most roles and missions. (Several specialists expressed concern that some AIP systems, like those based on fuel cells, require large volumes of extremely flammable matter like hydrogen and oxygen, and that the loading, handling, and usage of these chemicals by sailors have caused many fatal accidents in the past.) On the other hand AIP is proven and operational, since 1988 for Stirling engines in two navies and is soon to be operational in three more with additional submarines under contract. Costs could go down as production increases. Also more capable AIP platforms may reduce the need for larger numbers of diesel submarines for most roles and missions. Moreover, the Germans and French are designing their boats so AIP can be added if the buyer should desire that option after purchase. For example, Pakistan, a poor country, has ordered three Agosta-class submarines from the French at a cost of $\$ 930$ million. The third boat is to be equipped for AIP, but the other two will be retrofitted for AIP during their first major overhaul periods to accommodate technology timelines, not financial ones.

- There was disagreement over the spread of nuclear-powered submarines globally. The development or acquisition of nuclear submarines is extremely costly, and thus are not likely to spread beyond a few countries. They are also expensive to maintain and operate as evidenced by problems incurred by Russia and China. Nevertheless, India has a current effort to build nuclear submarines, called the Advanced Technology Vehicle program (ATV). Indeed, India leased a Charlie-class nuclear submarine in the late 1980 s from the Soviet Union. Recently, the Russians offered to transfer 2 Akulas to India, but India has decided against acquiring these submarines. For now, India has the only viable program, although Brazil has had such ambitions in the past.

- There was disagreement over how far Brazil's on again/off again program progressed with some arguing that the Brazilians succeeded in developing a prototype naval nuclear propulsion plant for a boat of about 2800 tons, according to Jane's Underwater Warfare Systems 2002-2003. (However, one specialist claims that they only tested a pump for a reactor, and the Brazilians cut off funding for the program in the early 1990's). Neither the Nuclear Nonproliferation Treaty (NPT) nor its Latin American equivalent, the Treaty of Tlatelolco provide a legal barrier to its signatories for the development of nuclear-powered submarines. For example, the Canadians would never have violated their NPT obligations by developing 10-12 nuclear submarines as they seriously considered in the late $1980 \mathrm{~s}$. The Treaty of Tlatelolco, specifically permits the development of nuclear propulsion, and, in this regard, the Brazilians have maintained that nuclear submarines provide "transportation," and are not weapons per se. Indeed, the Brazilians retained their right to develop nuclear-powered submarines in joining these treaty organizations, even though they currently lack the financial and technical means for a nuclear submarine program.

- Conventional submarines can be used as nuclear weapons platforms. For example, the Russians used the Golf-SSB for this purpose. The Chinese still have a Golf-class submarine, which has been used as a SLBM test bed. Some argued that the Israelis may be acquiring the Dolphin-class diesel submarine from Germany for this purpose. Indeed, the advent of AIP may make conventional submarines more attractive as a deterrent platform. Pakistan tried to buy a Han-class SSN from China in the $1980 \mathrm{~s}$, and has stated that it would equip its conventional submarines with nuclear weapons to offset any Indian capability. Some doubted that the Pakistanis have the scientific and technical capability to adapt their French submarines for WMD purposes. However, a nuclear device does not necessarily have to be delivered by torpedo or missile from a submarine to destroy a hostile port, according to one submariner.

Approved for public release; further dissemination unlimited 
- Some argued that a country needs an overall defense budget of a least $\$ 20$ billion to be able to afford a submarine program, and that expense severely limits submarine programs whether conventional or nuclear. Others point out that economic growth rates in many emerging economies may make submarine programs, even nuclear, more affordable in the future. For example, even Russia, which had negative growth rates for most of the $1990 \mathrm{~s}$, posted a growth rate of $1.5 \%$ in 1999 and $6.7 \%$ in 2000 . High oil prices over time may do wonders for the Russian economy. China has been scoring high growth rates since the advent of the Open Door policy in the late 1970s, and even India seems to have broken through its normal growth rate of $4 \%$ to post above $5 \%$ and $6 \%$ growth rates in recent years. All three of these countries also have significant and growing scientific and technological capabilities. Furthermore, economic development in the ASEAN countries has enabled many of them to purchase or consider acquiring submarines, for example Singapore and Malaysia. Economic clout gives Taiwan the ability to acquire or develop a submarine program if the Taiwanese can find someone willing to help them. South Korea, has been acquiring and assembling submarines with the help of Germany. The South Koreans are contracting for three S-214 AIP-equipped submarines from Germany to be assembled by Hyundai at Ulsan. The Japanese are also interested in improving their submarine capabilities with AIP-equipped boats. Finally, even relatively poor countries, like Iran and Pakistan, will buy submarines to satisfy perceived military requirements.

- There was some disagreement on how well some of these countries can operate these submarines. One specialist points out that operational proficiency among developing country submarine forces is widely varied even when operating the same type of platform. For example, China, India, and Iran operate Kilo class submarines, but their operational proficiency will vary widely. To measure operational proficiency, one must take into account:

— the professional quality of the submarines

- relative operational tempo

- normal area of operations

- periodicity of overhauls

- training facilities

— logistic support facilities

- service discipline-necessary to operate for prolonged duration and to gain tactical advantage under adverse conditions

- regularity of exercises including torpedo and mine laying exercises

- national capability to provide sufficient infrastructure support in country.

Ecuador, for example, does not operate them very well at all. However, friendly foreign submarines have succeeded in penetrating US carrier screens in recent exercises. The Indians believe that the Pakistanis are very capable submariners, and they themselves practice with the US in mind. As for Iran, 
it was not clear how well Iranian Kilos are manned and operated. However, it was argued that if we were really concerned we should simply mine Bandar Abbas, so they either could not exit or reenter after they left. Others pointed out that it was unlikely even in a crisis situation that the rules of engagement would permit mining Iranian harbors. In the past, Chinese submarine exercises have not ventured far from the coast, and they usually returned to port at the end of the day. However, the Chinese navy is moving towards more lengthy exercises in blue ocean waters. The Chinese nuclear submarine force has apparently become somewhat more active. In 1999, only one of four Han SSNs was operational, while China's only Xia SSBN was inactive. As of mid-2000, the Xia had resumed activity after a long overhaul, and two of the four Hans were operational.

- It was not clear there was any agreement on the impact of submarine programs on regional stability. However, India's effort to develop or acquire a nuclear submarine capability has prompted Pakistan to seek some offsetting capability in the past. Moreover, the Indians seem to be acquiring nuclear submarines as a way of projecting power in the seas around China. Such regional tensions should be a concern to the US since conflict between or among nuclear powers is a serious threat to global stability even though India's nuclear and conventional submarine programs may not be aimed at the US. Indeed, India cannot rule out that the US might "lean" towards Pakistan as Washington did in the Indo-Pakistani War of 1971. In that crisis, the US deployed the Enterprise carrier task force to the Indian Ocean as a warning to New Delhi not to occupy territory in West Pakistan. Thus, Indian submarine operations are conducted with the US in mind as well as Pakistan. Moreover, it probably is no accident that all the countries in the South China Sea region who could afford them are now acquiring or trying to acquire submarine capabilities. Of them, only Taiwan seems to have a reasonably clear reason for doing so unless the others are also concerned about Chinese intentions in the region. Even so, it seems that if an ASEAN state acquires a military capability the others want a similar one.

\section{What Other Questions or Issues Need Further Research?}

- Exactly how great has been the decline in US ASW capabilities, and what do we need to do about them? What about our allies?

- We need further research identifying diesel and/or AIP submarine vulnerabilities and new technologies that could help locate conventional submarines. Are there new technologies that would enhance a US SSN and other surface, air, sensor ASW assets' ability to detect conventional as well as nuclear submarines?

- We need further research into submarine-related military doctrine, strategy, tactics, operations, training and exercises of emerging nation submarine forces.

- How will general developments in science and technology affect submarine warfare in the future? For example, the development of the diesel engine for railroad use before World War II provided US submarines with greater speed and range. Among others, how will the exponential development of computing power in the future affect submarine technology, and how will submarines and ASW be integrated with "netcentric warfare?"

-What implications does the spread of submarines have for research in computer/software/algorithms, data management, materials sciences and engineering, weapons effects, MEMs technology, artificial intelligence, etc. 
- In the future, are there any potential breakthroughs in ASW that could render the US deterrent force vulnerable to attack? Is the export of ASW-related dual use technologies making our SSN/SSBN force potentially more vulnerable, for example, the export of detection equipment for seabed oil drilling and the use of SOSUS technology for academic related oceanographic research?

- How vulnerable are our SSN/SSBN submarines to a terrorist attack or takeover? What about nuclear submarines of other countries?

— Could Al Qaeda or some other terrorist organization acquire or exploit submarines from Iran, North Korea, or some future fundamentalist government in Pakistan, Algeria, Malaysia, etc. to launch a WMD attack on the US homeland, US bases overseas, or elsewhere?

- Could another country such as Iran use a conventional submarine, including midget submarines, to launch a sneak attack on a US port without us detecting their approach or even identifying the attacker afterwards?

What is the likelihood the submarines/submersibles could be used for drug smuggling or piracy or other criminal activities?

What is the likelihood that other countries (Israel or others) may use conventional submarines as deterrent platforms? Can they develop the requisite nuclear or WMD capabilities or missile or torpedo launched WMD? Do attackers need missiles or torpedoes, or could they just lay a WMD device in a port like a mine or place a device aboard a midget submarine or UUV? Have CBW capable-warheads been developed for submarines?

- There is also a need for further research on the probability of additional countries acquiring nuclear submarines, and the hazards they may pose to nuclear proliferation, safety and the environment, regional stability, and US naval operations. There is also a need to explore the interrelationship among US national security, proliferation, environmental safety, and Russian nuclear submarine dismantlement.

- What are the implications of the spread of submarines for arms control, nonproliferation, and export control arrangements?

- We should look more closely at how developing world submarine forces affect our ability to influence crises through naval diplomacy, especially among nuclear powers like India, Pakistan, and China as well as over a continuum of scenarios from peacetime operations to terrorism to confrontation or crisis to local war to conventional war to nuclear war.

- Although this workshop concentrated on discussing the current submarine threat, there is a need for further research on how the threat may evolve over the longer term, especially with the advent of a multipolar world.

\section{Comment and Conclusion}

The end of the Cold War seemed to create a more peaceful international environment. September 11, 2001 , reminded us of the dangers of complacency. Indeed, even before September 11 th, US forces had

Approved for public release; further dissemination unlimited 
intervened in a number of wars and crises, including Panama, the Persian Gulf, Somalia, Rwanda, Bosnia, Kosovo, several Taiwan Straits crises, the North Korea nuclear weapons crisis, Afghanistan, and, most recently, Iraq. US ability to intervene in remote areas of the world is often dependent on the Navy's ability to project power ashore. As a result, US ability to influence events in crisis situations, especially between or among nuclear powers, may become more difficult along with our ability to conduct littoral warfare.

Although the numbers of potentially hostile submarines have declined with the end of the Cold War, US anti-submarine warfare capabilities have also declined. Moreover, foreign submarines and related technologies are likely to diffuse globally. New technologies like AIP, improved weapons, and sensors will make conventional submarines more dangerous, and the spread of nuclear submarines even to other countries, such as India, could raise political, military, and environmental, and safety concerns.

Submarines are one of the key weapon systems used alone or in combination with other weapon systems such as coastal defense missiles, aircraft, and other sea-based missile platforms to deny US ability to project power ashore. Thus, other countries that wish to deny the US the ability to interfere with their regional or even global ambitions may emphasize the acquisition and/or development of submarines.

As the world becomes more multipolar over the longer term, countries, such as Russia, China, etc., may seek and be able to acquire the submarine capabilities to challenge us not just regionally, but in blue waters. To the extent that our alliance relationships require US naval access or superiority to sustain them, then our friends/allies, such as Japan, South Korea, ASEAN states, Taiwan, etc., may seek their own arrangements with other powers for their protection or seek WMD capabilities to offset their former reliance on the US. In addition to a loss of unchallenged regional access, the US may have to devote greater resources for protecting its homeland, and perhaps its sea-based deterrent, from hostile submarine forces. 


\title{
LIST OF TERMS
}

\begin{abstract}
AAW - Anti-air warfare
AG - Australia Group - international supplier regime to control Chemical/Biological Warfare related precursors and technology.

AIP - $\quad$ Air Independent Propulsion (Stirling engine, Fuel Cells, etc.): conventional submarines that do not rely on using a snorkel to obtain air to run the diesel engines to recharge their batteries while submerged. In the 1930s, Germany and Russia experimented with closedcycle engines for submarine propulsion. However, the German hydrogen-peroxide mix proved too dangerous for widespread use. In the 1970s, AIP began to be re-examined. The Swedes have developed a submarine with a Stirling engine with liquid oxygen storage, a battery for high burst speeds, and a diesel for recharging. Germany and others are developing boats with fuel cells, a proven technology, for cruising, with a battery for high speed operations and a diesel for recharging. There are variations on both these technologies.
\end{abstract}

ATV - Advanced Technology Vehicle: India's nuclear submarine program.

ASW - Anti-submarine Warfare

ASUW - Anti-surface Warfare

COCOM - Coordinating Committee for Multilateral Export Controls: the Cold War international organization that controlled munitions, dual-use, and nuclear related technology to the Communist bloc.

CVN - Nuclear-powered aircraft carrier

MTCR - Missile Technology Control Regime: international supplier regime to control missilerelated technology.

NSG - $\quad$ Nuclear Suppliers Group - international supplier regime to control nuclear weapons related technology.

R\&D - Research and Development

SLBM - Submarine launched ballistic missile

SS - Conventional submarine

SSAN - Auxiliary nuclear submarine

SSB - Ballistic missile conventional submarine

Approved for public release; further dissemination unlimited 
SSN - $\quad$ Nuclear-powered attack submarine

SSn - Small nuclear plant to generate electricity to charge batteries, which has yet to generate interest.

SSBN - Nuclear-powered ballistic missile submarine

SSGN - Nuclear-powered cruise missile submarine

UN - United Nations

UUV - Unmanned Underwater Vehicle

Wassenaar Regime; international supplier regime to control conventional weapons related technology including both conventional and nuclear submarines and related technology. However, controls in the Wassennaar Regime are considerably weaker than in the NSG, MTCR, and AG.

Key to Map on Submarine Production:

Producer-countries capable of developing and producing complete submarines.

Other Producers--countries which deserve special consideration: Japan has produced various classes of submarines, but does not export them as a matter of policy; and Australia has built the Collins-class submarine from a Swedish design.

Some Production-countries that have produced submarines in the past, have participated in joint ventures, have provided some assemble, interested in developing submarines or in acquiring some production capability.

Key to Map on Current Foreign Submarine Operations-Self Explanatory 


\section{SUBMARINE SUPPLIERS}

\section{Provider}

China

France (Spain)

Germany

Italy

Netherlands

North Korea

Russia (USSR)

\section{$\underline{\text { Recipient }}$}

North Korea (22 Romeo/Project 033 with 18 produced in NK). Egypt, (4 Romeo/Type 033 later modernized by US contractors and US torpedoes.) Produces or has produced a number of classes of nuclear and conventional submarines. Conventional: Romeo, Ming, building Song class ( 3 built). Nuclear: Han SSN (5), Xia SSBN (1), developing Type 93 SSN and Type 94 SSBN. Negotiated with provide Han SSN in late 1980s.

Chile (2 Scorpene 2004-2005), India (6-12 Scorpene on preliminary order), Malaysia (2 Scorpene/1 Agosta (used) Pakistan (1 Agosta-90 2 more building in country. 2 Agosta, 4 Daphne), Portugal (3 Daphne), Spain (4 Agosta, 4 Daphne, producing Scorpene with France), South Africa (2 Daphne). Also produces SSN/SSBN for France, and offered to transfer and/or construct Rubis-class SSNs in Canada in the late 1980s.

Argentina (2 TR-1700, 2 Type 209/1200), Brazil (4 Type 209/1400, 1 improved under construction), Chile (2 Type S-209/1300), Columbia (2 Type 209/1200), Denmark (3 Type 207), Ecuador (2 Type 209/1300), Greece (4 Type 214 AIP on order, 4 Type 209/1200, 4 Type 209/1100, 4 Type 209/1100), India (4 Type 209/1500, 2 with India), Indonesia (2 Type $209 / 1300$ ), Israel 3 Dolphin), Italy (2 Type 212A AIP with Italy), South Korea (3 Type 214 AIP, 9 Type 209/1200), Norway (6 Ula/Type 210), Peru (6 Type 209/1200), Poland (4 Type 207 from Norway), South Africa (3 Type 209/1400), Turkey ( 8 Type 209/1400, 4 in service, 4 building, 6 Type 209/1200), Venezuela (2 Type 209/1300)

Teaming with Germany to produce Type 212A AIP, retains residual submarine manufacturing capability

Taiwan (2 Hai Lung)

Vietnam (2 Sang-O coastal submarines). Has produced 19/22 Chinese Romeos.

Algeria (2 Kilo), China 2 Kilo/Project 636 with 9 on order, 2 Kilo/Project 877 EKM) Iran (3 Kilo/Project 877/EKM), India (2 Amur/Project 677E with 6 built in India may be ordered, 10 Kilo/Project 877EKM, 2 Foxtrot/Project 641M, 1 Foxtrot Project 641K), Poland (1 Kilo 877E), Romania (1 Kilo/Project 877E-non-operational), Ukraine (1 Foxtrot/Project 641-being reactivated). Russia produces both nuclear and conventional submarines. Has leased 1 Charlie-class SSGN to India. 1988- 
Sweden (Germany)

United Kingdom

United States

Other Producers

CO-Production Capacity

Retransfers
1991; India and Russia had discussions on transferring 2 Akula SSNs to India, but failed to come to an agreement.

Denmark (1 Nacken AIP), Singapore (4 Sjoormen), Australia (6 Type 471 Collins class. Germany's HDW now owns Kockums, the Swedish submarine manufacturer.

Canada (4 Upholder-class); retains some residual conventional submarine manufacturing capability. Produces or has produced SSN/SSBN, has 2 Astute-class SSN on order, 2 more planned; last SSBN delivered in 1999, no more planned; offered to transfer Trafalgar-class SSNs to Canada in late 1980s.

Taiwan (2 Guppy-llA for training: seeking partner to produce conventional submarines for Taiwan). No longer produces conventional submarines, but US shipyards interested in teaming with others to manufacture submarines for Taiwan. Produces nuclear submarines for own use, but does not export nuclear submarines/technology. US bank now owns $73 \%$ of HDW of Germany.

Australia (6 Swedish-designed Collins Type/471); Japan (4 Oyashio (4 building, 2 planned), 6 Harushio, 5 Yushio, 1 Harushio AIP in trails and training, 1 Yushio training; Japan does not export armaments as a matter of national policy).

Brazil (Type 209s with Germany; latent ambitions to produce nuclear submarines), India (Type 209s with Germany, developing ATV SSGN; Pakistan (Agosta-90s with France, South Korea (Type 214 AIP and Type 209 with Germany), Spain (produces Scorpene with France).

Countries that do not produce submarines can and do retransfer submarines to other countries. For example, Norway retransferred 4 German Type 207 to Poland.

Note: Table is a snapshot of submarine transfers in current inventories and where they came from as of May 2002. It is meant to be illustrative since sources can and do disagree. 


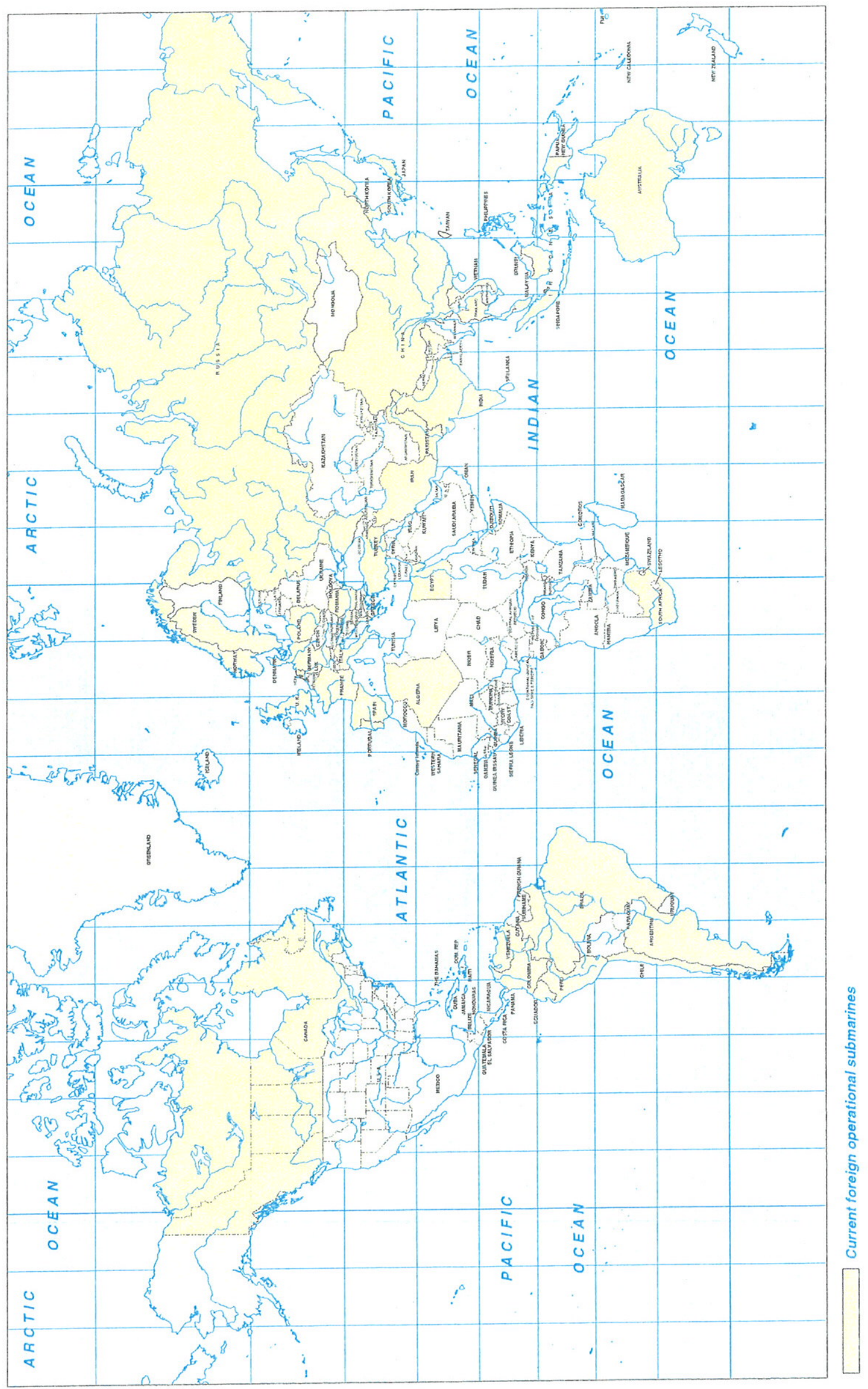




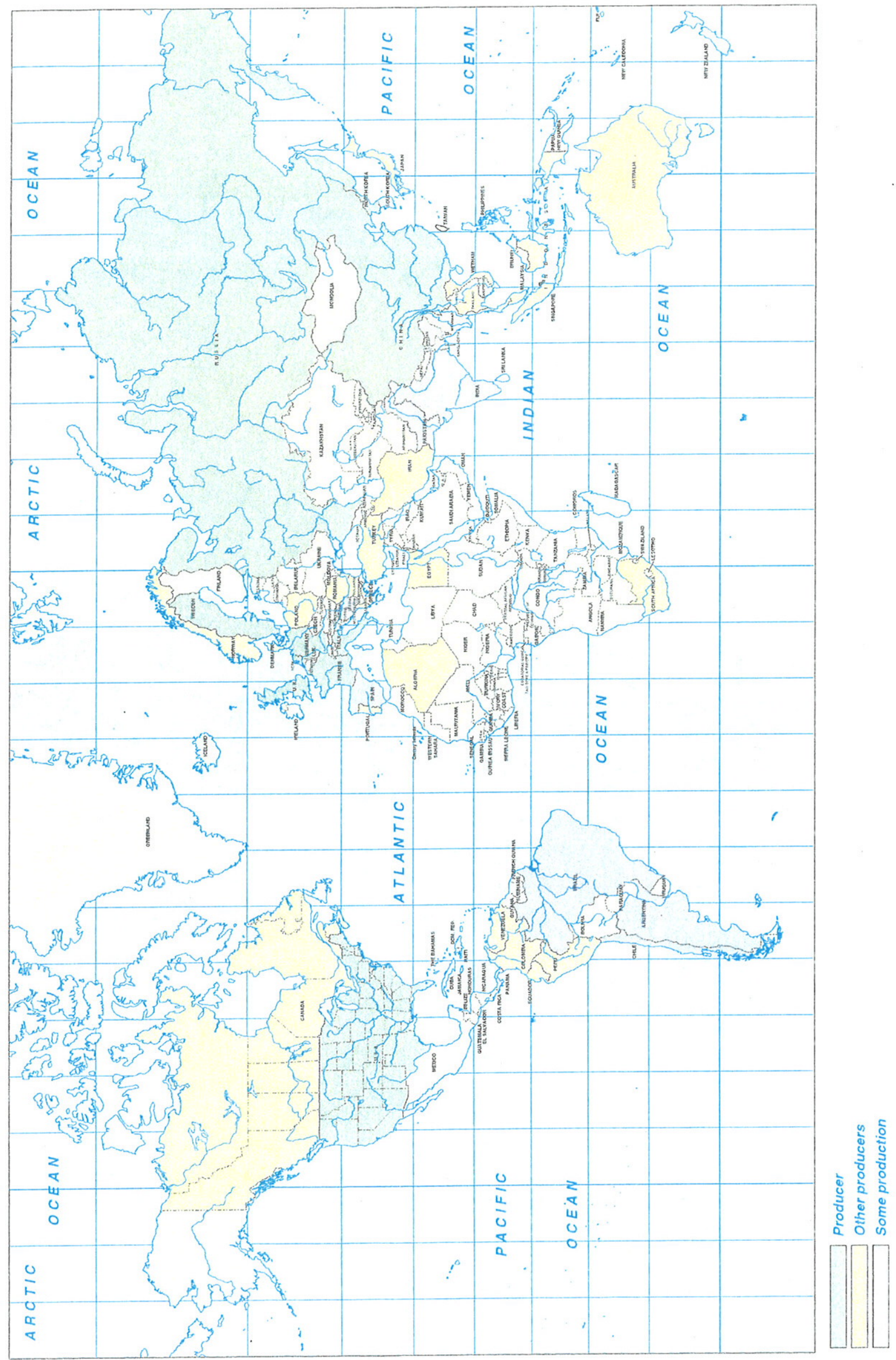

